\title{
Livestock production in Czechia and Slovakia, ten years beyond EU accession
}

\author{
Antonín Věžník*, Hana Svobodová, Jana Némethová, \\ Jakub Hradický
}

Masaryk University, Czechia

The contribution deals with the impact of the Common Agricultural Policy of the European Union on agriculture of the Czech and Slovak Republic, focusing on livestock production. The analysis is focused on ten years' development of livestock production after the entry of the Czech and Slovak Republic into the EU. Both countries are evaluated in the mutual comparison of selected indicators such as gross agricultural production, stock of animals, intensity of production or agricultural employment. Part of the contribution is the demonstration of the regional differentiation and trends in livestock production taking place in the Czech and Slovak Republic. In conclusion, we examine the consequences of decline in livestock production in the Czech and Slovak Republic reflected in the foreign trade between these countries, and it is closely connected with state sovereignty in livestock products.

Key Words: livestock production, Common Agricultural Policy of the European Union, agricultural employment, land use.

Article Info: Received: December 12, 2016; Revised: April 11, 2017; Accepted: May 10, 2017 ; Online: May 25, 2017.

\section{Introduction}

One of the indicators of both economic and agricultural development in the individual countries is the relationship between crop and livestock production and their share in the total gross agricultural production (GAP) respectively. It is generally acknowledged that the more advanced the economy, the more

* Corresponding author

Address: Masaryk University, Faculty of Science, Kotlářská 2, 61137 Brno,

Czechia.

Phone: +420549498210| Email:veznik@sci.muni.cz

(C)2017 Human Geographies; The authors

(c) (1) This work is licensed under a

Creative Commons Attribution 4.0 International License. DOI:10.5719/hgeo.2017.111.5 
advanced its agriculture - the share of livestock production is higher than the share of crop production. The share of livestock production in the total gross agricultural production on the territory of the Czech Republic (hereinafter only CR) was the highest in the 1980's, for instance in the year 1986 it amounted to $59.4 \%$. After the year 1990 when both the Czech and Slovak agriculture underwent major social and economic changes this share has been constantly dropping and the overall volume of livestock production is on the decrease too. In the year 2001 the share of livestock production totalled to merely $53.4 \%$ in CR and to $55.2 \%$ in SR (Věžník, Král, Svobodová 2013, Némethová, Dubcová, Kramáreková 2014). It is therefore evident that based on the comparison of development of this production in constant and regular prices this decrease has not ceased. It is further obvious that this decrease, which was particularly striking in the first years of the economic reform, did not completely stop even during the period prior to the accession to the European Union (EU) at the turn of the millennium.

The fact that the volume of livestock production has been permanently falling also after the entry into the EU and compared to previous five years this drop is even more significant, poses a threat for future development. (Bečvářová et al. 2008). The decrease is that dramatic that it changes the original relationship of the two basic sectors of agricultural production. The traditionally higher share of livestock production understood also as a certain factor of finalizing crop production with a higher degree of added value of the original production is no longer preserved. The reduction of livestock production is subsequently reflected in the changed numbers of livestock. The stock of cattle decreased from the original 3506 thousand heads in the year 1990 to 1353 thousand heads in the year 2013, however, this drop was accompanied by a significant increase in performance, especially milk performance.

The pig numbers that culminated in the year 1981 (5 106 thousand pieces) have dropped to the present 1617 thousand pigs. It means that the overall production volume has fallen. It is both the products based on cattle breeding (milk, beef) and pig breeding (pork) (SZP po roce 2014..., 2014), which have recorded a considerable decrease. In Slovakia the situation is similar. In the year 1990 in Slovakia 1563 thousand heads of cattle were bred, while nowadays (information based on the year 2013) it is approximately only one third (467.8 thousand heads). The decrease in pig breeding has been even more significant from 2521 thousand pigs in the year 1990 to the current 647 thousand pigs. According to Chrastinová et al. (2014) livestock production in Slovakia has been showing a decreasing tendency over the long term, which is connected with the economic conditions such as for example higher cost of livestock breeding. The drop in production is further strongly linked also to the import of products to the local market.

\section{Theoretical background}

Several Anglo-Saxon authors (e.g. Ilbery, Bowler, 1998; Wilson, 2001) deal with the changes in European agriculture over the last twenty years. They conceptualize the alternation in agriculture on the basis of the regulation theory and the 
theory of flexible specialization (inspired by Fordism and post-Fordism). In a simplified way they claim that European agriculture has changed from an intensive (production oriented) mode to a post-intensive (post-productive) mode and that it is continuously changing into a mode of multifunctional agriculture. Wilson (2007) understands it as a wide scale of the approaches of the stakeholders in agricultural activities and sets forth a number of typical signs of transformation. The difficulty of theoretical formulation of the changes and the interest in this topic is supported by a series of critical texts (Evans, 2002; Potter and Tizley, 2005; Ward et al. 2008). For instance Potter and Tizley (2005) object that agriculture in the prevailing neoliberal practices has been more polarized to production areas. The result is offering favourable conditions for agriculture, which is extensified. Those areas can be understood as an alternative consumption space for the population (of non-production character from the point of view of food production).

The changes in agriculture are motivated by the current shape of the Common Agricultural Policy of the EU (hereinafter only CAP), which increasingly desists from granting benefits for the production and the product and places more emphasis on the protection of environment, creation and preservation of landscape, food security and good conditions for livestock farming. (Ward et al., 2008). Vaishar and Zapletalová (2009) point out that agriculture is ever more in the role of a landscape "preserver" in the majority of micro regions situated near the borders due to the fact that these areas are marked by not very suitable conditions for agriculture. Also Věžník, Král and Svobodová (2013) cover the issue of the declining agriculture in CR especially after the accession to the EU.With regard to the fact that the current development tendencies of agrorural structures lead to bigger socioeconomic differences among the individual regions, this topic is pivotal for a number of geographical works (Jančák, Götz 1997, Věžník, Bartošová 2004, Spišiak, Lelkés 2003, Hasiński 1999, Věžník, Svobodová, Zvara 2008, Némethová 2009a, 2009b, Spišiak, Némethová 2008 etc.).

The effort to assess the individual prerequisites for agricultural revitalization and the strengthening of its non-production functions enlarged by the rural opportunities for development are coming to the fore in line with the development of the EU's CAP (Spišiak 2005, Shucksmith et al. 2007, Ramiceanu, Ackrill 2007). Sadowski a Czubak (2013) presented a more recent analysis (the period between 2007 and 2013) of selected priorities in the field of rural development in the EU states. Maye (2013) particularly assessed and analysed agricultural multifunctionality in the context of food security, climate change in connection with the changes in the use of land. A number of agricultural economists such as for example Doucha, Foltýn (2008) or Štolbová, Hlavsa (2008) analysed the evaluation of changes in Czech agriculture especially after CR's accession to the EU. An analysis of income disparities in Czech agriculture covered for example Boháčková and Hrabánková (2008).

It is obvious that a number of foreign authors have dealt with the impact of the EU's CAP on the development of agriculture. For example in Portugal Santos et al. (2010) concentrated on the attitude of the individual farmers towards the impacts of the EU's CAP. In Slovakia Uhrinčat'ová (2011) analysed in detail the potential scenarios of the EU's CAP after the year 2013. In Poland 
Rudnicki (2013) assessed the situation from the perspective of the beneficiaries of EU funding. Gorton et al. (2008) dealt with the approach and the statements of selected farmers from the new EU member states particularly focussing on the changes in the EU's CAP after the year 2003. Maye and Ilbery (2009) analysed the results of diversification and the changes in the rents of English farmers under the influence of the CAP. Buday et al. (2012) examine the comparison of the impact of the CAP on the development of agricultural output - products and volume of foreign trade in the EU-27 states since 2004. Falt'anová (2008) concentrated on the expected influence of the EU agricultural policy on the development of agricultural output in SR.

The impacts of the transformation period and the period after Slovakia's accession to the EU were reflected in the overall use of agricultural land. After the year 1989 a change occurred in Slovakia regarding the use of agricultural land - cultivated agricultural land started to become desolate, which is manifested in spontaneous growing of non-forest trees and bushes on meadows and pasture land.

These processes take place in particular as a result of the overall stagnation of agriculture, especially livestock production (Zaušková, Midriak, Krajčovič, 2012). According to Blacksell (2010) agriculture still has a considerable influence on the creation of landscape and the way, in which this sector is going to evolve is therefore of key importance for the future of the European environment. Geographical literature does not offer many articles covering exclusively the topic of livestock production. This is the reason why we primarily used the databases of the Czech Statistical Office (ČSÚ), the Statistical Office of SR (̌́SUS), the Food and Agriculture Organisation of the United Nations (FAO) for the purpose of this article, as there are literally lack of information in the subject in geographical literature. The next valuable sources were the works of Kvapilík et al. (2014), Špička et al. (2009), Palát et al. (2012) and also Ilbery and Maye (2005) who analysed selected changes in the trends of cattle farming and their importance with regards to supplying the food market in Great Britain.

\section{Data and methods}

With respect to the absence of a geographical analysis dealing with the impacts of the Common Agricultural Policy of the EU on livestock production the main objective of this article is to evaluate and compare the impacts of the Common Agricultural Policy of the EU on the agriculture in the Czech and Slovak Republics while focussing on livestock production. As a matter of fact since the year 1989 and also after EU accession livestock production has been going through a more dynamic change than crop production. These changes are ultimately reflected in crop production, use of land (e.g. reduction of crop area for fodder crop or reduced cultivation of fodder crop on one hand and an increased share of permanent grassland on the other) and agricultural employment (livestock production requires considerably more employees than crop production; Veleba 2012).

In order to follow the development of livestock production we will use the time series of data from the agricultural sector in the period between 2005 and 
2015 from the Czech Statistical Office (ČSÚ) and the Statistical Office of the Slovak Republic (Š́́S) and as the case may be the data from Eurostat (the data is almost identical with the data of ČSÚ and ŠÚS, however in some details they slightly vary), for comparing the trends we will use the figures of the EU-15 states (i.e. states, which entered the EU before CR and SR, the so called "old EU member states) and the EU-10 states (i.e. all the states that acceded to the EU in the year 2004; other three states that entered the EU later will not be taken into consideration).

The ten-year-period starting in the year 2005 was chosen with the aim to cover the state of agriculture directly after the accession of CR and SR to the EU (the year 2004). The year 2015 is selected as the final year that provides complete data. By means of the 10-year-time series it is already possible to assess how the measures of the EU's CAP influence the agricultural sector in both countries, in particular their livestock production.

We will specifically follow the development of the following indicators:

1. The numbers of the individual animal species in the period between 2005 and 2015 in CR and SR in absolute values.

2. Self-sufficiency of CR and SR in production (the relationship of production and consumption of the given commodity).

3. The impact of cattle breeding on the crop area of fodder plants in CR and SR. This indicator is being analysed by means of the correlation coefficient, which defines the direct or indirect dependency between two variables. The correlation coefficient equals the values from -1 to +1 , which indicate a linear relationship (negative or positive). In case there is no linear relationship the result equals 0 . The correlation coefficient was calculated in the MS Excel programme according to this formula:

$$
\rho_{x, y}=\frac{\operatorname{cov}(X, Y)}{\sigma_{x} \sigma_{y}}
$$

where $\rho$ is the correlation coefficient and $\sigma$ is the value of the variables $x, y$ of the chance quantities $\mathrm{X}, \mathrm{Y}$.

4. The number of employees in agriculture per 100 ha of agricultural land (relative employment) in the period between 2003 and 2013 in CR, SR, EU-15, EU-10 and EU-28.

The data comparison for CR and SR is accounted for by the common history between the years 1918 and 1992, however even before and after these years the development of both countries was always in a certain way interlinked. Both states entered the EU on 1 May 2004, which influenced the economic development of both states. However, the inventions by the states themselves cannot be neglected.

\section{Changes in livestock production in CR and SR}

Since the Czech and Slovak Republics entered the European Union in 2004 the overall framework, the philosophy, the level of support, the forms and the degree of regulatory interventions in agriculture and in the agrarian sector are principally subject to the framework, the rules and limitations of the Common Agricultural Policy of the EU (Bečvářová et al. 2008). 


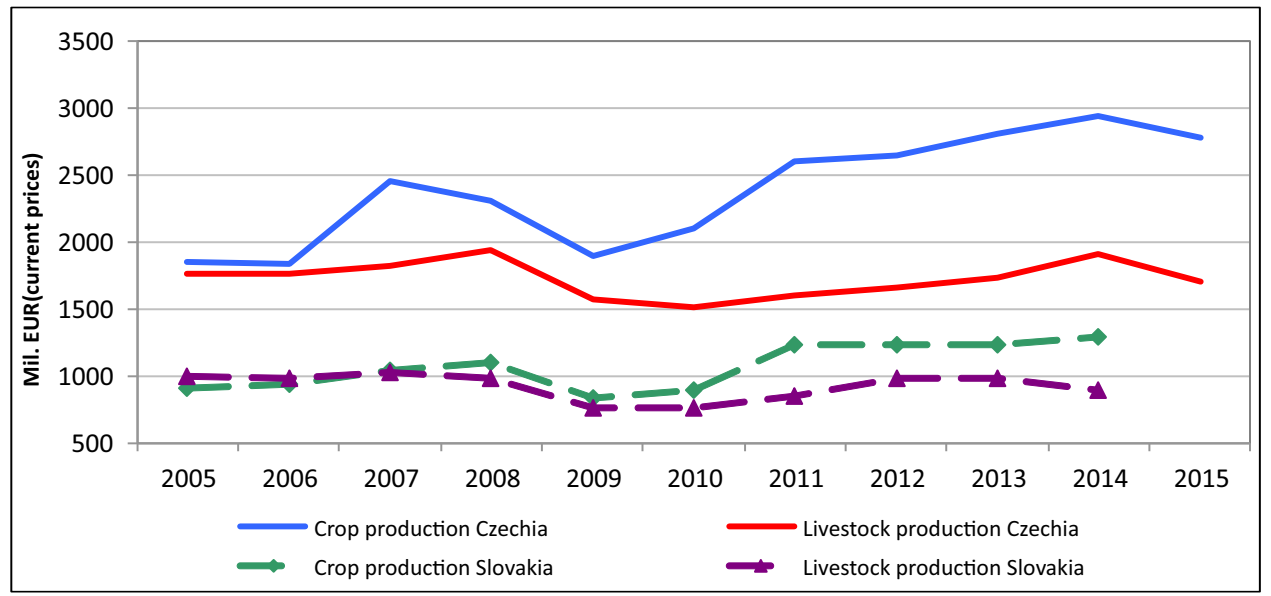

Figure 1. Crop and livestock production in CR and SR between 2005 and 2015

Data source: Czech Statistical Office, Statistical Office of SR; author's own elaboration

The counties of Central and Eastern Europe that joined the EU in the year 2004 considerably lagged behind the performance of the original states of the European Union. Their development was also conditioned by the uneven level of agricultural subsidies in the individual EU-27 member states. (Blažík, Falt’an, Charvát, Mlynarčík, Spišiak, 2014). One of the reasons for the decrease in livestock production in SR is the lower level of support compared to the old EU member states that resulted in the technical and technological lagging behind of Slovak businesses. These businesses lack capital and this fact makes them increase the prices in order to cover the cost, however, the customers are not able to pay them in the long term. The worst situation is in the field of breeding cattle, pigs and poultry, while it is exactly these areas of livestock production that have the potential to generate numerous job opportunities.

The increasing competition on the common EU market, the problems with the sales and uneven conditions for farming between the old and new EU member states have led to further reduction in the numbers of livestock, in particularly of pigs and cattle, which has been reflected in the decrease of livestock production due to the reduction of the manufacturing capacities and the dissolution of a series of meat processing businesses.

One of the basic indicators of agricultural development is the gross agricultural production (GAP) measured in permanent prices. Czechoslovak agriculture was highly efficient in the first half of the 1990's, as changes in society started to arise in late 1990's due to the change of regime. At present its performance is drastically lagging behind and its structure is changing to the disadvantage of the final livestock production. The decrease in livestock production is strongly linked to the reduced numbers of livestock but also to the import of finished products from abroad. The Common Agricultural Policy by means of its instruments motivated the farmers to limit livestock production and develop crop production, in particular the growing of large-scale crops, the manufacturing process of which can be managed by mechanisms and a small number of staff. (Serenčéš, Mučaji 2014). The volume of agricultural production in CR and SR went down, crop production gained the upper hand over livestock production (Figure 1) and the extensive types of farming expanded. Generally over the 


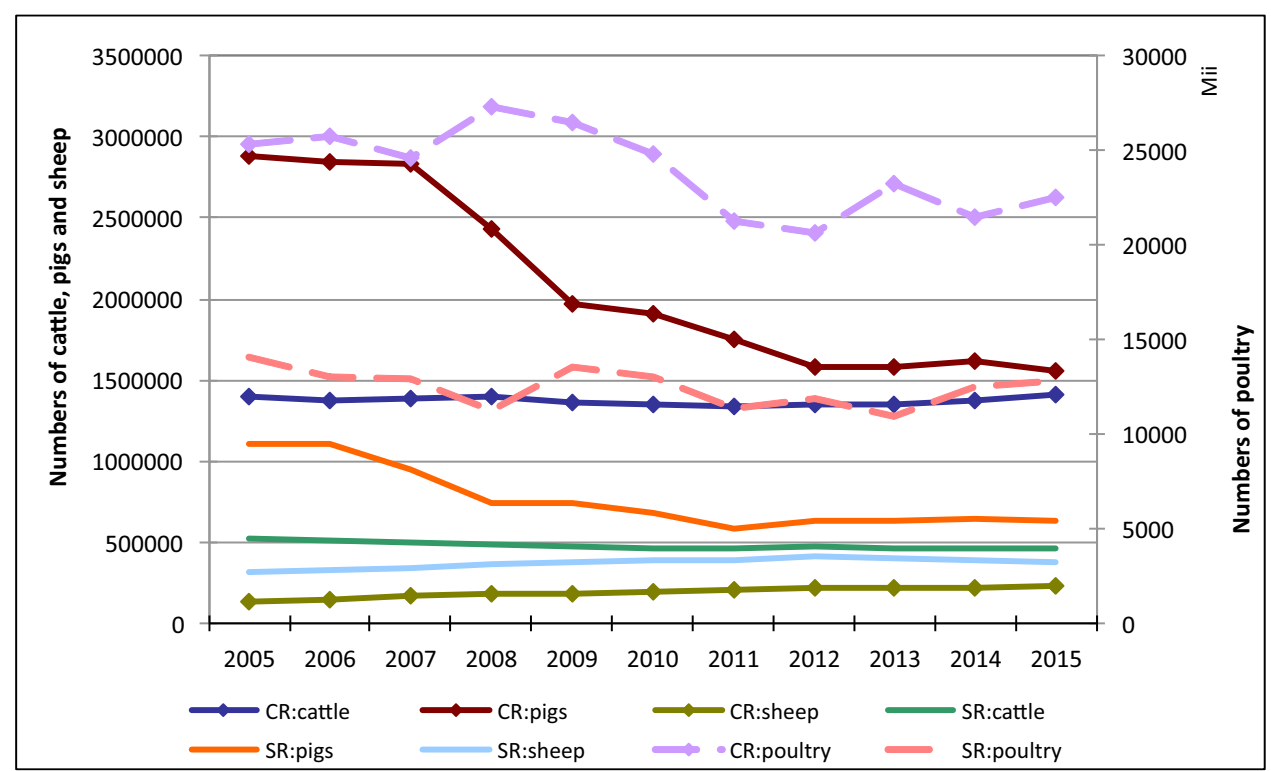

Figure 2. Development of livestock numbers in CR and SR in the period 2005-2015 Data source: Czech Statistical Office, Statistical Office of SR; author's own elaboration

last twenty years the number of farm animals has been lowering, however the performance has gone up. After CR and SR's entering the EU the expected stabilization did not occur, on the contrary in case of some types of livestock the decreasing trend even deteriorated (Vize Českého zemědělství, adapted).

The changes in livestock production are primarily caused by the uneven conditions for the old and new EU member states and the incorrectly set funding schemes in the years after the accession of both states to the EU. This inequality brought about a considerable reduction in the numbers of pigs and cattle and thus led to the loss of self-sufficiency in meat production, both in CR and SR. Both states that were self-sufficient in meat production prior to EU accession are currently dependent on import, especially the import of pork and poultry meat. In Slovakia the numbers of livestock not only extremely fell down. In some regions livestock farming entirely disappeared. The dependence on the import of some commodities, which yet are frequently of lower quality than the Czech and Slovak products, is therefore constantly growing (see below). The volume of Czech and Slovak agriculture is therefore diminishing while changing its structure - the production of raw materials dominates over finished products.

Regional differences in livestock production in CR and SR

Livestock production presents an important part of agricultural production. However, the past 25 years have seen a rapid decrease in the breeding of some animal species (Figure 2) and an internal change in their structure, the breeding methods and in the position of agriculture within the food vertical. The regional disparities in the Czech and Slovak agricultures result mainly from historic development that was determined by different soil types and climatic conditions in the lowlands, in the highlands and in the mountain and submontane areas. Varying production and economic conditions (soil type and climatic conditions, 
impact of agricultural transformation and restructuring, sectoral specialization of agricultural businesses) in the agrarian sector influence the agricultural production in the individual areas in the Czech Republic and Slovakia.

In the production areas (lowlands) a bigger decrease of the numbers of livestock has been recorded in comparison to the submontane areas. The reduction in these areas commenced already during the transformation period in the 1990's. It is regions that have the most favourable conditions for crop production and therefore in these regions livestock production is less important. As to livestock production it is especially pig and poultry farming that prevail in these areas. Crop production in these areas provides sufficient fodder resources for this type of stockbreeding. One of the main objectives of the CAP is also the support and maintenance of agricultural production in the EU disadvantaged areas (mountain areas or marginal areas etc.). These regions have most suffered from intensive agricultural production in the period prior to the transformation (soil erosion etc.). It is exactly in these regions where livestock production is of major importance for rural economy and preservation of agricultural production. The regions are characterized by a moderate increase in cattle numbers especially cows without market production of milk (CMPM); they play a role particularly in landscape preservation. However, on the other hand, agriculture including livestock production is in the Czech and Slovak Republics becoming more extensive and more ecological (Niggli, 2008).

The biggest change in the numbers of the bred livestock can be seen in pig farming. Between the years 2005 and 2015 the drop presented 54.2 percentage points in CR and 57.1 percentage points (hereinafter only pip) in Slovakia. The main reason were the unevenly defined conditions for the individual EU states, which means the import of "less expensive", i.e. more subsidized meat from the Western European countries and also from Poland, which is capable of subsidizing agricultural production from national resources. In the Central European countries (mainly in Czech and Slovak Republic) the farm-gate meat prices are not able to cover the cost of stockbreeding. Apart from the low farm-gate price for meat the falling number of stockbreeders is also due to the subvention policy and the support of farmers that are different from Poland.

In Poland the subventions are tied to production and the farmers additionally receive significant funding from national resources. Polish farmers are motivated to produce more in order to receive higher funding. The subventions enable them to sell meat at different prices than the Czech or Slovak stockbreeders. The drop in pig numbers has occurred in all regions in CR, while in 2005 most pigs were bred in the South Moravian region, which after a decade dropped to the third place (after the Central Bohemian region and the Vysočina (Highlands) region). The increase in the numbers of cattle in CR in the period under consideration is negligible by 0.7 pip between the years 2005 and 2015, however certain regional differences are apparent - while in some regions there was a decline, in others the numbers rose. At this point it is necessary to mention that a rapid decrease of cattle numbers in the Czech Republic occurred mainly in the 1990's (more e.g. Bičík, Jančák 2005, p. 72-74). Even after ten years two regions remain predominant, the South Bohemian region and the Vysočina region. In the Karlovy Vary and Liberec region the numbers of cattle have risen (Figure 3). 


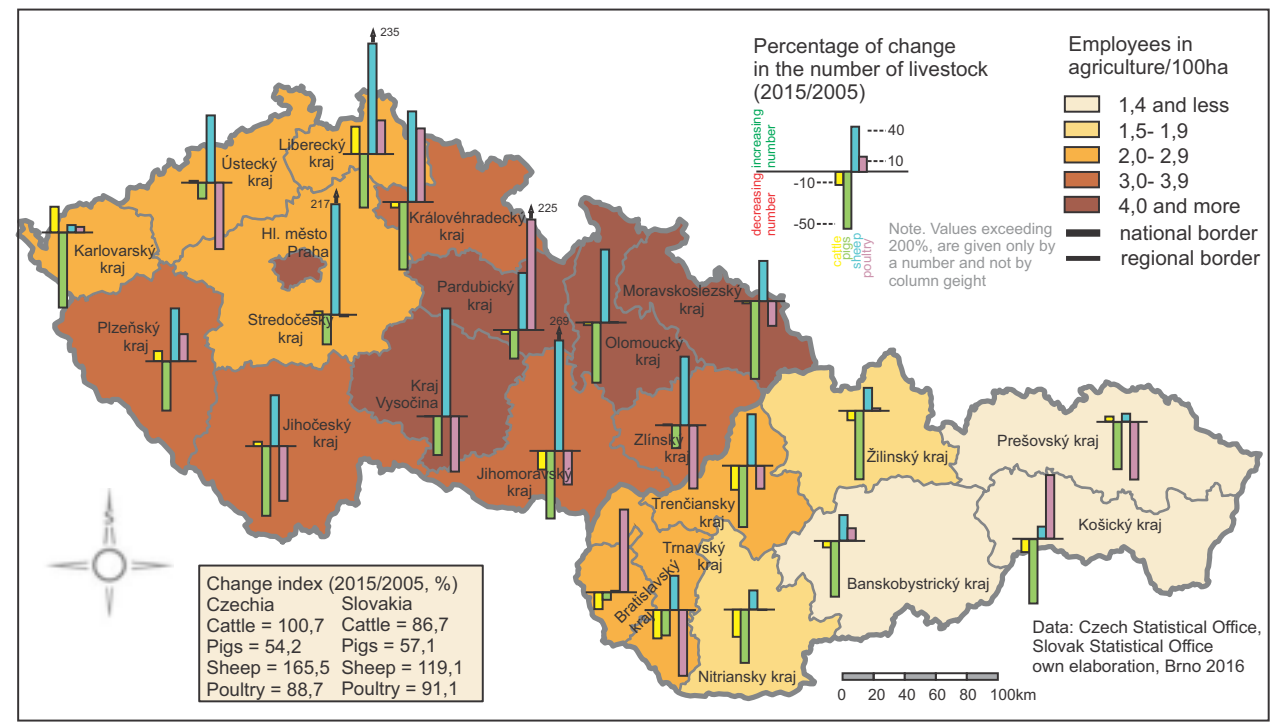

Figure 3. Change in the number of livestock in the Czech and Slovak regions $(2015 / 2005)$

In Slovakia the numbers of pigs and cattle declined in all the regions. In Slovakia the decrease in the numbers of cattle is far more serious - by 13.3 pip. The development of the breeding of cattle and milked cows is mainly influenced by the unsatisfactory economic results, especially the milk prices that are lower than in the EU-15 states. Almost in all Slovak regions there was a decline in the numbers of cattle. The increasing numbers of CMPM cows prevented a bigger decrease in CR as well as in SR (Kvapilík, Růžička, Buček, 2014), the breeding of which is linked to permanent grassland and receives subsidies. This kind of husbandry is important especially in the submontane and mountain regions, mainly in the agriculturally disadvantaged regions in landscape preservation, in which livestock production has a dominating position. In Slovakia the CMPM cow farming recorded an increase of $79.45 \%$. In the case of the numbers of dairy cows a decrease was recorded in all regions. In Slovakia this decline amounts to $28.18 \%$.

With regards to sheep farming in the CR in all regions there was a significant increase of the number (by 65.5 pip) and this mainly due to the fact that prior to EU accession the numbers of sheep was at a minimum and that is also why a small increase in the numbers mean a relatively big increase. As it was the case with cattle the biggest reduction of sheep numbers occurred in the first years of the transformation period. It is the South Bohemian region that has been holding the first place in the number of bred sheep over a long term. In Slovakia the sheep numbers increased moderately (by $19.1 \mathrm{pip}$ ). In all the regions except Bratislava and Nitra there was a moderate increase in sheep numbers. The biggest increase was recorded in the Trenčín region, however the first place when it comes to sheep numbers belongs to the Banská Bystrica region. Generally the increase in both countries is recorded particularly in those regions, in which sheep farming is most spread, i.e. in the regions located at a higher altitude. Also here the funding system under the EU's CAP plays a role, which results in fostering sheep farming on permanent grassland. 
The numbers of poultry in CR and SR over the period under consideration from 2005 to 2015 declined too. In the CR the decline is slightly more moderate (-11.3 pip), however the CR is at present no more self-sufficient in the production of poultry meat. Slovakia saw a decrease by 8.9 pip (in all the regions of Slovakia) and the local market is compelled to import poultry meat. The main reason for the decline in production in CR and SR is the opened European market, thanks to which poultry meat is imported especially from Poland and to Slovakia also from Hungary. Domestic production of poultry meat is also weakened by the policy of multinational supermarket chains, which frequently prefer foreign suppliers of poultry meat to the local ones, as the foreign importers offer a significantly lower price than the Czech or Slovak producers. No trend can be noticed in poultry farming. In some regions there was an increase, whereas some regions recorded a decrease, both in CR and SR.

\section{Agricultural employment}

It is necessary to understand the overall development of agricultural production as a process, which is to a great extent regionally differentiated. (See e.g. Jančák, Götz 1997; Perlín, Hupková 2010; Věžník, Konečný 2011). While crop production is more dependent on the physical and geographical conditions, livestock production is at present influenced especially by the EU subsidy system. The subsidy system namely in a significant way influences the strategies of the farmers (Špička, Boudný, Janotová 2009).

The difference between CR and SR is clearly visible in the employment in the primary sector. As Figure 3 shows the employment per 100 ha is in CR (3.5\%) significantly higher than in Slovakia $(1.6 \%)$. The differences are even more pronounced within the individual regions - the highest employment is according to ČSÚ data in the capital city of Prague, where farmers are merely registered. However, in reality the highest employment is in the Praha region (7.55 $\%)$, the Olomouc region (4.49\%) and in the Vysočina (Highlands) region and the Moravian-Silesian region (both $4.45 \%$ ). In Slovakia the highest employment is in the Bratislava region (2.2\%) and the Trenčín region and the Trnava region attain more than $2 \%(2.03 \%, 2.05 \%$ respectively).

Higher agricultural employment applies to the lowlands and submontane areas. Agricultural employment reflects the state of livestock production, as it employs a big number of staff in the primary sector. The decreasing trend in agricultural employment could not even be halted by the accession of CR and SR to the EU. The lack of support compared to abroad led to Slovakia's losing job opportunities in livestock production. In spite of the fact that the EU's CAP attempts in various forms to maintain agricultural employment (e.g. subsidies for young farmers), low wages, which render this sector less attractive, do not contribute to increasing the employment rate.

In most EU regions agriculture only accounts for a small part of the overall EU employment. Also in those regions in the countries of Central and Eastern Europe (e.g. Rumania, Bulgaria, Poland, Lithuania) and of Southern Europe (e.g. Greece, Spain and Portugal), where agricultural employment is of higher importance, there is the tendency of shifting this employment to other sectors. The diversification of agricultural activities presents an important source of 
rural employment, in particular in the field of e.g. processing of agricultural raw materials, services and agrotourism.

According to Buchta (2010) the decrease of labour force in agriculture is an accompanying effect of continuous restructuring of the agrarian sector. When it comes to the creation of jobs the role agriculture is getting increasingly less important. This is why future prospects of employment in the agrarian sector will mainly depend on the increase of production performance, modernization, improved quality of human capital and on a diversified use of the endogenous development potential of rural economy. On the other hand agriculture is gradually disposing of unqualified labour force (type of work in agriculture and a low degree of technological development indicate that the process of "crowding out" the insufficiently qualified employees will be a lengthy one) and that the sector is possibly going to employ more seasonal workers (Buchta 2013).

\section{Consequences of ten years of decreased livestock production}

The consequences of livestock production decrease in CR and SR have numerous impacts on national economy and its trade balance, which is closely connected with the (self) sufficiency in production. The indirect impact can be seen i. a. in the use of land and the employment in the primary sector.

From the point of view of self-sufficiency in livestock production CR is not doing well. Over the 10 years in the EU the self-sufficiency in pork meat production plunged to $55 \%$ (mid 2014), the remaining volume must be imported. The poultry meat produced in CR covers approximately four fifths of the consumption. In beef CR is self-sufficient and $30 \%$ of beef is being exported, the same as one quarter of milk, however without added value. In order to cover the egg consumption it is necessary to import approximately $10 \%$. From this follows that the farming trend in livestock production does not very well correspond to the consumption. Looking back 25 years we consume about one third of beef, however the production fell only marginally and therefore a big part of beef is for export. On the other hand we eat 2.5 times more poultry meat. The consumption of pork and milk was more or less on the same level over the long term. The consumption of eggs significantly decreased (Statistika \& my, 7/2014).

Back in 2005 Slovakia was self-sufficient in the production of beef and poultry meat. Since that time the production and consumption of beef and poultry meat has been constantly decreasing, just like the consumption of meat per inhabitant. In 2005 less pork meat was produced than consumed. Approximately $7 \%$ of the consumption was covered by import. Nowadays Slovakia is no longer self-sufficient in the production of any kind of meat. In poultry meat domestic production covers about 50-60\%, more than $50 \%$ is imported despite to the fact that its consumption unlike the consumption of beef and poultry meat, which is falling, has been stable over the long term. Pork meat is being imported to Slovakia from almost all of Europe but mainly from the neighbouring countries. More than a half of the slaughter pigs are being exported as a result of closing down of numerous important slaughter houses, e.g. in Lučenec, Rimavská Sobota, Humenné, Zbrojníky or Sered'. At present there are only smaller slaughterhouses in Myjava, Tešedíkovo or Komárno that 


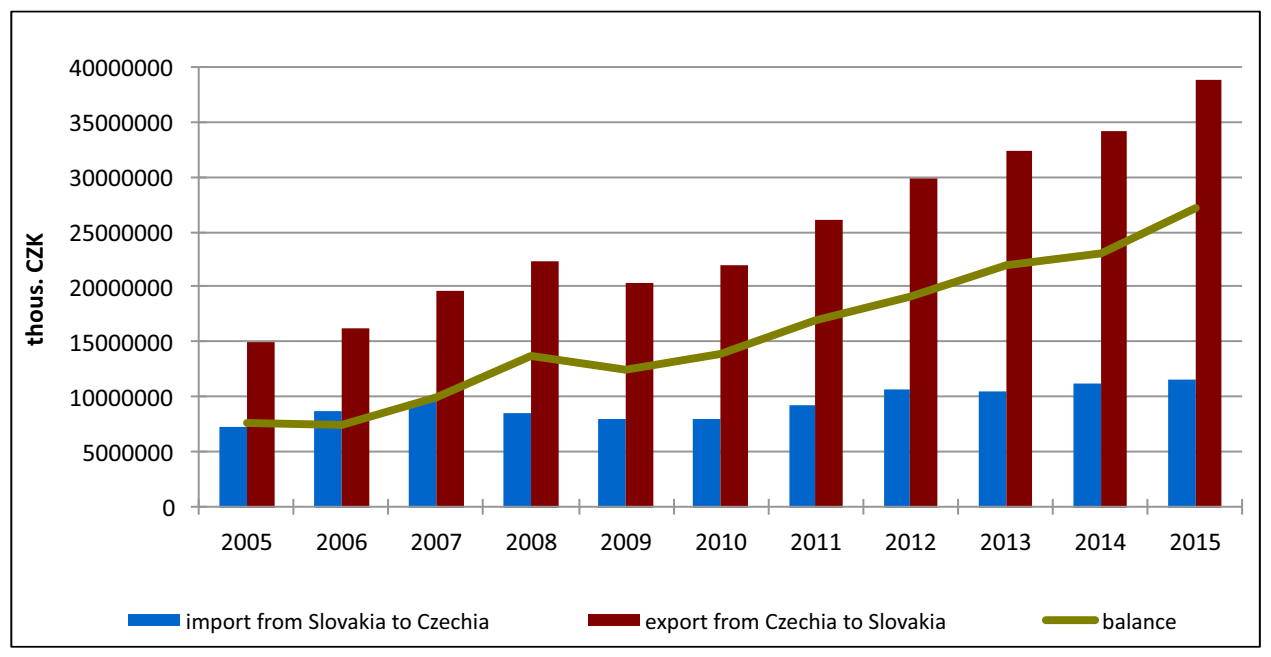

Figure 4. Foreign trade balance - livestock products (SITC 0 - food and live animals) between CR and SR in the years 2005-2015

Data source: ČSÚ foreign trade database, author's own elaboration

operate and which until recently were of local importance only. Most slaughterhouses in Slovakia process meat from foreign production, which is economically more advantageous for them. Slovakia is trying to kick-start pig farming that was constantly ignored from the part of the EU or by the own state. The consumption of milk and eggs is balanced.

The negative development in livestock production is naturally in a significant reflected in foreign trade. A complete analysis of the foreign trade in livestock products offer the articles of for example Svobodová (2014) or Svatoš and Smutka $(2010,2012)$. In this paper we are only going to analyse foreign trade in agricultural products (class SITC 0) between CR and SR. The volume of foreign trade between CR and SR is rising, the balance is positive for CR, i.e. more livestock products are exported to Slovakia and vice versa Slovakia imports more products from CR (Figure 4). Farmers sell their products there, where they have advantageous prices and therefore it frequently happens that Czech unprocessed products leave the country and return as finished products with a high added value.

The decline in livestock production in CR has a relatively significant impact on the structure of the cultivated crops especially fodder crop. Their area mainly correlates with the numbers of ruminants, whose numbers have been gradually decreasing since 1990. Most fodder crops were grown in CR and SR in the 1980's. After this time their crop area was decreasing hand in hand with the declining numbers of cattle. The fodder crops cultivated on arable land presented in CR almost $20 \%$ of the crop area in the year 2003, in the year 2013 it was only $18.3 \%$. Recently there has been a moderate increase in the crop area with a significant share of maize, which is used as biomass for electricity production.

In Slovakia in the period under consideration, i.e. from 2003 to 2013, an increase of the crop area of perennial fodder crops by 26.2 pip was recorded. This increase is conditioned by gradual improvement of permanent grassland and transformation of arable land of lower value especially in the submontane 
regions. An increase in the crop area of fodder crops was recorded particularly in the Žilina, Banská Bystrica and Prešov regions.

The decline in the crop area of fodder crops is strongly linked to the numbers of cattle, which in the case of CR are validated in the results of the correlation. The value of the correlation coefficient between the numbers of cattle and the area of fodder crops on arable land presents for CR +0.737921 , while a value of the correlation coefficient amounting to +1 would indicate a direct dependency. This value thus implies a relatively high dependency of both quantities. However, in Slovakia the situation is the complete opposite and the correlation coefficient totalled to a value of -0.83992 , which means that no dependency could be confirmed in this case.

\section{Discussion}

In May 2014 it was 10 years since CR and SR and other Central and Eastern European countries joined the EU. The impact of the CR's and SR's 10-yearmembership in this European organization on the agrarian sector is not unambiguous. In the majority of cases it is the making of profit from entreprenial activities at national level, the international trade opportunities, European subsidies into agriculture over the past years that are being assessed as positive. Less positive are mainly the facts related to stagnation and reduction of "dimensions” with some commodities (Kvapilík, Růžička, Buček, 2014).

The decline in the overall agricultural production was associated with a decline in the gross livestock production. The decline in production is closely related to the decrease in the numbers of almost all species of livestock. The structural imbalance in agricultural production is still increasing, while livestock production presents a lower share in agricultural production. The most crucial in the field of livestock production is pig and cattle farming. The decline struck especially dairy cow farming, particularly in areas that are agriculturally productive. On the other hand the numbers of CMPM cows went up mainly in the areas that are less suitable for agricultural production. In these areas extensive farming is slowly prevailing, in which dairy cow farming is being replaced by CMPM cow farming. Poultry farming underwent an adverse development, which brought about a moderate decline. Over the past 20 years the numbers of sheep have fallen but in the period under consideration between 2005 and 2015 sheep breeding recorded an increase.

It is not only the long-term low prices paid to agricultural producers that liquidate domestic livestock production in both states but especially the massive importation of meat and dairy products with a higher added value. In cases where domestic production falls the most, self-sufficiency also decreases below an acceptable limit. As an example serves the production of pork meat, which over the past 10 year plunged, same as the self-sufficiency of this commodity (České zemědělství..., 2012).

The new development concept (until the year 2020) of Czech agriculture primarily targets the change of the unfavourable development in Czech agriculture and the food processing industry. Here we summarize the main steps:

1. Preservation of the basic production areas, preservation of the fertile and 
cultural agricultural land while caring for the soil, sources of water and air.

2. Restoration of a balanced structure between crop production and livestock production with the aim to foster their growth.

3. Production of high-quality food from own sources and winning over the competition.

4. Creation of jobs in rural areas, while providing a solid social background and opportunities for self-realization to the employees, as rural areas are being depopulated.

In a nutshell it is necessary to put the Czech agriculture back onto the way of growth, considering that Czech agriculture has a much bigger potential than it presently uses (SZP po roce $2014 \ldots, 2014$ ). The vision is clear - less cereals and rape in the fields, the more fodder crop, potatoes, sugar-beet, leguminous plants, hop and vegetables, more cattle, pigs and poultry in the stables and on the meadows, lower unemployment rate in rural areas and more food made in Czech Republic in the stores.

The Ministry of Agriculture of the Slovak Republic in the new programming period 2014-2020 decided to increase the level of financial support for the breeding of certain livestock species, e.g. dairy cow farming, pig farming and fattening pigs farms, broiler chickens and sheep (Rural development programme of SR 2014-2020, 2015). The Slovak documents emphasize far more than the Czech documents the reanimation of the declining livestock production. In case of crop production the operative word is fruit and vegetable growing. Slovakia identically with the Czech Republic has the potential to change the current unfavourable situation and obtain full self-sufficiency in meat production and even export some commodities. (e. g. sheep meat for which there is no demand on our markets). Also the change in behaviour of the consumers who over the last years have been paying more attention to the origin and quality of food and the expanding market with fresh products directly from the producer on the local market aim for fostering production.

The present trends in employment in the agrarian sector clearly show that agricultural population is growing old and the levels of employment in this sector constantly go down. Not only the EU will have to bring into focus this unfavourable situation but also both states. The endeavour to foster small-scale farmers should result in creating new jobs in rural areas and at the same time contribute to producing more domestic food. The departure of young people namely impacts livestock production, which is more vulnerable and more longranged compared to crop production. Encouraging young farmers, ensuring continuity from one generation to the next and regaining the importance and dimensions of Czech and Slovak agriculture currently poses a real challenge for the development not only of agriculture but also of all rural areas in the Czech Republic and in Slovakia (according to the Common Agricultural Policy, Partnership between Europe and Farmers, 2012).

Livestock production ranks among the most important sectors in agricultural production from the point of view of preserving and developing agrarian and rural employment. The unfavourable development of livestock production negatively influences the foreign trade of both countries. The comparison between the Czech Republic and Slovakia shows that it is Slovakia, which imports more livestock products from the Czech Republic. The increase in 
livestock production is slower in Slovakia, domestic demand cannot be covered by domestic production and therefore Slovakia is compelled to import a considerable amount of finished food products.

\section{References}

Bečvářová, V (ed) 2008, Vývoj českého zemědělství v evropském kontextu, Mendlova zemědělská a lesnická univerzita, Brno.

Bičík, I \& Jančák, V 2005, Transformační procesy v českém zemědělstuí po roce 1990, Univerzita Karlova v Praze, Praha.

Blacksell, M 2010, 'Agriculture and Landscape in 21st Century Europe: The PostCommunist Transition', European Countryside, vol. 2, no. 1, pp. 13-24.

Blažík, T, Falt’an, V, Charvát, T, Mlynarčík, J \& Spišiak, P 2014, 'Analýza trhu s pol'nohospodárskou pôdou na Slovensku na príklade okresov Dunajská Streda a Liptovský Mikuláš v kontexte transformačných procesov po roku 1989', Geografickýčasopis, vol. 66, no. 1, pp. 67-85.

Buchta, S 2010, 'Vývojové trendy v oblasti ekonomiky práce v pol'nohospodárstve SR', Ekonomika pol'nohospodárstva, vol. 10, np. 3, pp. 3-10.

Buchta, S 2013, 'Agrárna zamestnanost' a možnosti tvorby nových pracovných miest', Ekonomika pol'nohospodárstva, vol. 13, no. 2, pp. 51-68.

Buday, $\breve{S}$ (ed) 2012, Porovnanie dopadov SPP na vývoj pol'nohospodárskej výroby a objem zahraničného obchodu, Výskumný ústav ekonomiky pol’nohospodárstva a potravinárstva, Bratislava.

Český statistický úřad 2012, 'České zemědělství', Agrární komora ČR, Př́loha Zpravodaje Agrobase, Praha, viewed 30 June 2015, https://www.czso.cz/.

Chrastinová, Z (ed) 2014, 'Ekonomická efektívnost' chovu hovädzieho dobytka a oviec', Ekonomika pol'nohospodárstva, vol. 14, no. 4, pp. 104.

ČSÚ 2001, 'Soupis hospodářských zvíratat k 1. 3. 2001', viewed 30 June 2015, https://goo.gl/vZEi3f.

ČSÚ 2002; 2005; 2008; 2009, 'Hrubá zemědělská produkce za rok 2001, 2004, 2007, 2008', viewed 30 June 2015, https://goo.gl/dCwvMQ.

ČSÚ 2008, 'Strukturální výsledky za zemědělství v roce 2007', viewed 30 June 2015 , https://goo.gl/kXy28z.

Dos Santos, MJPL, Henriques, PD, Fragoso, RM \& Carvalho, MLPV 2010, 'Attitudes of the Portuguese farmers to the EU Common Agricultural Policy', Agricultural Economics, vol. 6, no. 10, pp. 460-469.

Evens, N, Morris, C \& Winter, M 2002, 'Conceptualizing agriculture: a critique of post-productivism as the new orthodoxy', Progress in Human Geography, vol. 26, no. 3, pp. 313-332.

Falt’anová, N 2008, Očakávané vplyvy agrárnej politiky EÚ na vývoj pol’nohospodárskej výroby $S R$, Prognostický ústav SAV, Bratislava.

Gorton, S, Douarin, E, Davidova, S \& Latruffe, L 2008, 'Attitudes to agricultural policy and farming futures in the context of the 2003 CAP reform: A comparison of farmers in selected established and new member states', Journal of Rural Studies, vol. 24, no. 3, pp. 322-336.

Hasiński, W 1999, Rolnictvo indywidualne na Dolnym Slasku w okresie transformaci systemowej, Uniwersytet Wroclawski, Wroclaw. 
Ilbery, BW \& Bowler, IR 1998, 'From agricultural productivism to postproductivism', in B Ilbery (ed), The geography of rural change, Addison Wesley Longmann Limited, Essex, pp. 57-84.

Ilbery, B \& Maye, D 2005, 'Alternative (shorter) food supply chains and specialist livestock products in the Scottish-English borders', Environment and Planning A, vol. 37, no. 5, pp. 823-844.

Jančák, V \& Götz, A 1997, Územni diferenciace českého zemědělství a její vývoj, Univerzita Karlova, Praha.

Kvapilík, J, Růžička, Z \& Buček, P 2014, Ročenka chov skotuv České republice 2013.

Maye, D 2013, 'Reassessing agricultural multifunctionality in the context of food security, climate change and the new land use debate', New Rural Spaces. Towards renewable energies, multifunctional farming, and sustainable tourism, Brno ÚGN, pp. $60-71$.

Maye, D, Ilbery, B \& Watts, D 2009, 'Farm diversification, tenancy and CAP reform: Results from a survey of tenant farmers in England', Journal of Rural Studies, vol. 25, no. 3, pp. 333-342.

MZe ČR 2003; 2004; 2007; 2009, Zemědělství 2002; 2003; 2006; 2008, pp. 105; 94; $140 ; 124$.

MZe ČR 2003; 2009, Situační a výhledová zpráva: Skot - hovězí maso, prosinec 2002; 2008, pp. 72; pp. 80.

MZe ČR 2004; 2009, Situačni a výhledová zpráva: Vepřové maso, červenec 2004; srpen 2009, pp. 63; pp. 72.

MZe ČR 2009, Situačni a výhledová zpráva: Mléko, prosinec 2008, pp. 118.

MZe ČR 2010, Souhrn ke Zprávě o stavu zemědělství ČR za rok 2009, pp. 21.

Némethová, J, Dubcová, A \& Kramáreková, H 2014, 'Impacts of the European Union's common agricultural policy on agriculture in Slovakia', Moravian Geographical Reports, vol. 22, no. 4, pp. 51-64.

Némethová, J 2009a, Agropotravinárske štruktúry okresu Nitra, Univerzita Konštantína Filozofa, Nitra.

Némethová, J 2009b, 'Agroštruktúry vysokoprodukčného regiónu Slovenska = Agricultural structures of a highly productive region in Slovakia', Ekonomika polnnohospodárstva, vol. 9, no. 2, pp. 50-58.

Niggli, U 2008, 'Ekologické zemědělství - cesta pro udržitelnost v zemědělské praxi', in B Šarapatka \& U Niggli (eds) Zemědělství a krajina: cesty k vzájemnému souladu, Univerzita Palackého, Olomouc.

Palát, M, Dvořaková, Š \& Kupková, N 2012, 'Consumption of beef in the Czech Republic', Agricultural Economics, vol. 58, no. 7, pp. 308-314.

Perlín, R \& Hupková, M (eds) 2010, Venkovy a venkované, Univerzita Karlova, Praha.

Potter, C \& Tizley, M 2005, 'Agricultural policy discourses in the European postFordist transition: neoliberalism, neomercantilism and multifunctionality', Progress in Human Geography, vol. 29, no. 5, pp. 581-600.

Program rozvoja vidieka SR 2014-2020 2015, viewed 10 February 2015, file://C:/Users/user/Downloads/navrh_strategickeho_dokumentu_program_roz voja_vidieka_sr_na_programovacie_obdobie_2014_\%E2\%80\%93_2020.pdf.

Ramniceanu, I \& Ackrill, R 2007, 'EU rural development policy in the new member states: Promoting multifunctionality', Journal of Rural Studies, vol. 23, no. 3, pp. 416-429.

Rudnicki, R 2013, 'Spatial differences in the number of applications for payments 
under the EU common agricultural policy submitted by agricultural holdings in Poland over the years 2002-2010', Quaestiones Geographicae, vol. 32, no. 4, pp. 15-31.

Sadowski, A \& Czubak, W 2013, 'The priorities of rural development in the EU countries in years 2007-2013', Agricultural Economics, vol. 59, no. 2, pp. 58-73.

Serenčéš, R \& Mučaji, I 2014, 'Spoločná pol'nohospodárska politika EÚ a SR', in Improving performance of agriculture and the economy: challenges for management and policy: proceedings of reviewed articles of 13th international scientific conference, Nitra, May 21-23, 2014, High Tatras, Slovak University of Agriculture in Nitra, pp. 154-158.

Shucksmith, M, Thompson, KJ \& Roberts, D 2005, CAP and the regions: The territorial impact of the Common agricultural policy, CAB I publishing, Wallingford.

Špička, J, Boudný, J \& Janotová, B 2009, 'The role of subsidies in managing the operating risk of agricultural enterprises', Agricultural Economics, vol. 55, no. 4, viewed 15 March 2014, pp. 169-179, https://goo.gl/enrpQV.

Spišiak, P (eds) 2005, Agrorurálne štruktury Slovenska po roku 1989, Geografika, Bratislava.

Spišiak, P \& Lelkés, G 2003, 'Vybrané problémy agroštruktúr vo vysokoprodukčnej pol'nohospodárskej oblasti Slovenska - Dolnonitriansky region', in Geografické aspekty středoevropského prostoru, Masarykova univerzita, Brno, pp. 122-127.

Spišiak, P \& Némethová, J 2008, 'Agrosubjekty regiónu Nitra vo vzt’ahu k odberatel'om pol'nohospodárskych surovín', Geografický časopis, vol. 60, no. 1, pp. 63-87.

Spoločná pol'nohospodárska politika Partnerstvo Európy a pol'nohospodárov 2012, viewed 24 September 2015, https://goo.gl/ZYXC9k.

Štatistický úrad Slovenskej republiky viewed 30 June 2015 , http://slovak.statistics.sk/.

Statistika \& my 7/2014, viewed 30 June 2015, https://goo.gl/uUa5Jp.

Štolbová, M \& Hlavsa, T 2008, 'The impact of the LFA payments on the FADN farms in the Czech Republic', Agricultural Economics, vol. 54, no. 10, pp. 489-497.

Svatoš, M \& Smutka, L 2010, 'Development of agricultural foreign trade in the countries of Central Europe', Agricultural Economics, vol. 56, no. 4, pp. 163-175.

Svatoš M., Smutka L., (2012), "Development of agricultural trade and competitiveness of the commodity structures of individual countries of the Visegrad Group”, Agricultural Economics, vol.58. nr.5, p.222-238.

Svobodová, H 2014, 'Changes on Foreign Trade in Agricultural Commodities in the Czech Republic', Journal of Central European Agriculture, vol. 15, no. 2, pp. 62-72.

SZP po roce 2014 2014, Zemědělskýtýdeník, vol. 17, np. 48, pp. 50, 52.

Turnock, D 1997, The East European economy in context: communism and transition, Routledge, London.

Uhrinčat'ová, E 2011, 'Effects of the Common Agricultural Policy potential scenarios after 2013 in the Slovak Republic', Agricultural Economics, vol. 57, no. 1, pp. 27-34.

Vaishar, A \& Zapletalová, J 2009, 'Sustainable development of rural microregions in the Czech borderland', Moravian Geographical Reports, vol. 17, no. 4, pp. 34-43.

Veleba, J 2012, Pád českého zemědělstvíje užkonečnětřeba zastavit, Právo.

Věžník, A \& Bartošová, L 2004, 'Selected regional geographical differences of the 
Czech Republic agriculture, after the transformation processes', Agricultural Economics, vol. 50, no. 5, pp. 207-216.

Věžník, A \& Konečný, O 2011, 'Agriculture of the Czech Republic after Accession to the EU: Regional Differentiation', Moravian Geographical Reports, vol. 19, no 1, pp. 50-60.

Věžník, A, Král, M \& Svobodová, H 2013, 'Agriculture of the Czech Republic in the 21 st Century: From Productivism to Post-productivism', Quaestiones Geographicae, vol. 32, no. 4, pp. 7-14.

Věžník, A, Svobodová, H \& Zvara, J 2008, 'Possible impacts of the common agricultural policy reform on development of agriculture in the Jihlava district', in Geography in Czechia and Slovakia. Theory and Practice at the Onset of 21st Century, Masaryk University, Brno, pp. 201-206.

VIZE Českého zemědělství 2010, VIZE Českého zemědělství, Ministerstvo zemědělství ČR, Praha.

Ward, N, Jackson, P, Russell, P \& Wilkinson, K 2008, 'Productivism, PostProductivism and European Agricultural Reform: The Case of Sugar', Sociologia Ruralis, vol. 48, no. 2, pp. 118-132.

Wilson, GA 2001, 'From productivism to post-productivism ... and back again? Exploring the (un)changed natural and mental landscapes of European agriculture', Transactions of the Institute of British Geographers, vol. 26, no. 1, pp. 77-102.

Wilson, GA 2007, Multifunctional agriculture: a transition theory perspective, CABI, Cambridge.

Zaušková, L', Midriak, R \& Krajčovič, V 2012, 'Dopady transformačného obdobia a obdobia po vstupe Slovenska do EÚ na zmeny využívania pol'nohospodárskej krajiny', Ekonomika pol'nohospodárstva, vol. 12, no. 4, pp. 98-106. 